\title{
Noore põdra püha
}

\author{
Ülo Siimets
}

Oli käes septembri lõpp. Jõudsime tagasi jarangade juurde. Kari jäi mõned kilomeetrid jarangadest eemale. Karjavalvesse jäid Veem ja Nuwat.

Ejgeli läks elama oma jarangasse. Minule anti magamiseks polog (jarangas asuv õhukesest riidest magamistelk) brigadir Remkölömi jarangasse. Teda kutsuti tavaliselt vene nimega Ivan Ivanovitšiks.

Polog asus jaranga sissekäigust lõkke suunas vaadates vasakul. Samas pologis oli ka Vatapi magamisase. Ivan Ivanovitši suur polog asus otse lõkke taga ja seal magas ta koos kahe väiksema lapsega. Suuremad lapsed, kui nad ei olnud internaatkoolis, magasid samuti suures pologis.

Lõkkesuits täitis jaranga ülaosa sissepääsuava eest kõrvale tõmmatud nahkade ülemise ääreni. Tšuktšid olid väikest kasvu ja neil aitas kergest ettepoole kummardamisest, et pea ei oleks suitsu sees. Mina aga pidin selleks sügavalt kummarduma.

Jarangasse tulles istusime kolmekesi rätsepistes lõkke taha põdranahkadele madala paarikümne sentimeetri kõrguse laua äärde.

Septembri algul oli jarangade juures käinud helikopter. Sellega oli toodud juurde toiduaineid, mis ladustati ühte tühjana hoitud jarangasse. Toodi jahu, makarone, tangaineid, konserve, suhkrut, konservpiima, teed, tubakat ja muud hädavajalikku. Kopteri peamine ülesanne oli võtta kaasa suvevaheajal jarangades viibivad koolilapsed, kes septembrist mai lõpuni elasid kooli internaadis puumajadest külas. Toiduaineid toodi siis muu hulgas kopteriga kaasa.

Laojarangast võttis igaüks nii palju toitaineid kui ta ühe korraga ära sõi või perele toiduks keetis. Keegi mingisugust arvet ei pidanud. Selles suhtes, nagu ka mõnes muus toimetuses valitses Tšuktšimaal juba kommunism.

Jarangade elanikud ja kontrollisid toiduaineid ainult saabumisel, võrreldes, kas kõik vastab nimekirjadele. Toiduainete eest maksid karjas käivad karjused, kellelt võeti söödud koguse eest võrdselt palgast maha. Ei olnud tähtis, kui suur oli kellegi pere.

http://haldjas.folklore.ee/tagused/nr19/poder.pdf 


\section{Ülo Siimets}

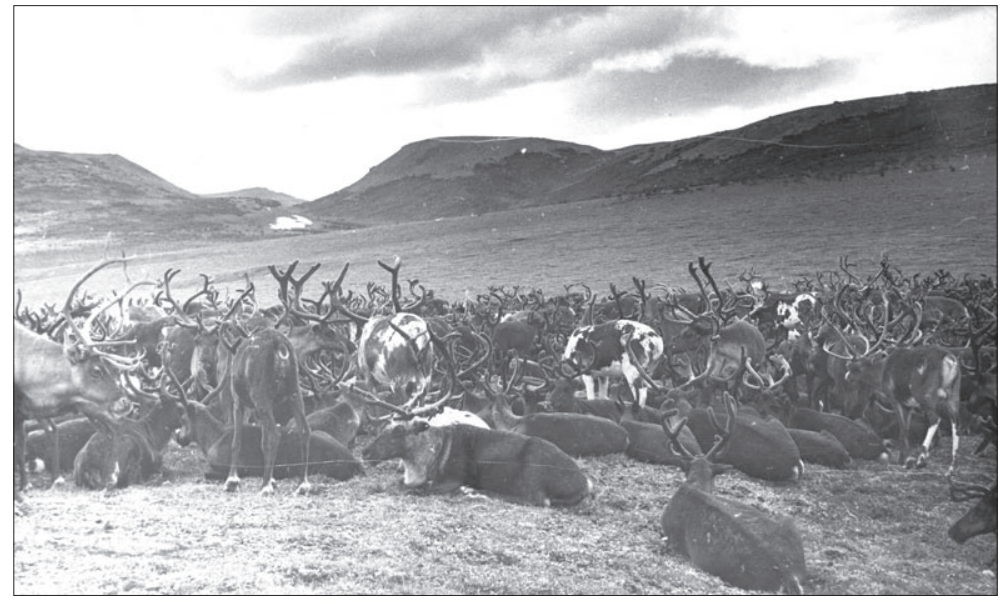

Joonis 1. Põdrakari puhkamas. September 1971. Foto: Erik Filips.

Lapsed õppisid esimesel aastal koolis ainult vene keelt. Edaspidi õpiti kõiki aineid vene keeles. Tšuktši keelt oli võimalik õppida pärast 8. klassi fakultatiivainena.

Lapsed ei tahtnud kodust ära minna. Tšuktšid rääkisid, et nad jooksvat sügiseti helikopteri saabudes alati mööda tundrat laiali. Siis algavat kopteriga tõeline lastejaht. Kopter tõuseb õhku ja ülevalt on hästi näha, kus lapsed asuvad. Nad püütakse kinni ja korjatakse kopteri pardale. Väiksemad kinnipüütud lapsed karjuvad ja nutavad, aga kord on kord - nad peavad kooli minema. Kooli internaadis räägivad nad omavahel vene keelt. Isegi jarangades olles oli huvitav jälgida, et vanemad räägivad omavahel ja lastega tšuktši keeles, aga lapsed vastavad neile vene keeles. Kui vanemad öeldust aru ei saa, siis seletatakse juurde ka tšuktši keeles.

Keskkooli lõpetamise ajaks on lastest saanud venestunud inimesed, kes enam ei taha minna põdrakarja, vaid püüavad leida mingisugust tööd suuremates külades ja linnades. Puumajadest külas rääkisid kõik noored omavahel vene keelt ja sellise poliitika tulemusel on põdrakarjas enamasti vanemad mehed.

Istusime laua ääres. Pereema võttis madalast puukastist tassid ja kallas meile teed. Lauale puistati suhkrutükid ja karamellkompvekid. Ivan Ivanovitši naine oli keetnud riisiputru. Pudru kõrvale 
anti ka kuivikuid, kuivatatud liha ja tšuktši võid (põdrakondirasva). Puder söödud, korjati kausid kokku ja viidi jarangast välja, kus koerad need puhtaks lakkusid.

Tšuktšid ise väidavad, et koerad on väga puhtad loomad ja nende keelel on desinfitseeriv toime. Usutakse, et kui mõni inimene on haige, tapab koer oma keelega kõik kausil olevad bakterid - isegi tuberkuloosi. Peale selle ei lase koera keel ketljadel (pahadel vaimudel) kaussidesse jääda. Kui kohtasime karjaga liikudes geolooge ning olime neilt liha vastu makarone ja suhkrut vahetanud, lasti koertel pärast makaronide keetmist ja söömist lakkuda puhtaks nii kausid kui ka pada.

Tee joomisel oli huvitav jälgida, et perenaine seisis kogu aeg oma mehe selja taga. Kui kellelgi sai teetass tühjaks, tõttas perenaine lõkke juurde, võttis konksu otsast kuumas seisva teekannu ja valas tassi uuesti täis. Tasse täideti seni, kuni jooja teetassi kummuli keeras.

Kuskil eemal asuvas jarangas hakkas põrisema bubin. Küsisin Remkölömilt, kes seal trummi taob. Ta vastas:

"Ejgeli võtab vaimudega ühendust."

"Ma lähen vaatan."

"Selle püha rituaali ajal ei tohi keegi teda segada. Tema jarangasse ei tohi ka ilma loata minna."

Ma isegi ei küsinud enam, miks. Elu tundras tšuktšide seas oli selgeks teinud, et ega õiget vastust nende käest saagi. Tšuktšide rahvakommetest olid nõus valgetele rääkima vaid vähesed põhiliselt kõrgharidusega inimesed.

Pärast õhtusööki heitsime pologisse põdranahkade vahele magama. Õigemini püüdsime magama jääda, aga see ei õnnestunud. Vestlesime Vatapiga ühest ja teisest. Lõpuks trumm vaikis ja me uinusime.

Hommikul ärkasin hirmsa ähkimise ja imeliku kriuksumise peale - Vatap oli varakult, mind äratamata pologist lahkunud.

Algul arvasin, et pereema ja pereisa viivad läbi oma hommikust seksuaalakti. Lebasin pologis, kuid kui ähkimine ei lõppenud, piilusin pologit katva riide vahelt välja. Oma üllatuseks nägin lõkkeaseme ees põlvitavat perenaist, kelle ülakeha oli kuni vööni paljas. Tal oli käes mingi vibu moodi asi. Vibunööri keskele oli kinnitatud puupulk, mis toetus otsapidi ovaalsele liuakujulisele umbes $40 \mathrm{~cm}$ pikkusele ja 15 laiusele lauatükile. Lauatükis oli kuus ümmargust pesa, millest ühes oli sammal või kuivatatud hein. Naine ei kandnud rinnahoidjat 


\section{Ülo Siimets}

ja ta paljad rinnad olid rippu. Ta nühkis meeleheitlikult vibuga edasitagasi, keha higist läikimas, pühkides käeseljaga aeg-ajalt otsaesist.

Jarangaavast tuli sisse Remkölöm.

"Noh, kas ei õnnestu?" küsis ta pisut pahase häälega.

"Sammal on vist niiske," vastas naine.

Seepeale tõmbas mees nahksärgi üle pea ja põlvitas naise juurde. Ta võttis vibu enda kätte ja hakkas kiiresti seda edasi-tagasi liigutama. Mõne minuti pärast tõusis liuapesast suitsuvine. Mees hakkas veel kiiremini vibu liigutama, kummardudes allapoole ja puhudes suitsevale heina-samblatuustile. Ka naine aitas tal puhuda. Järgmisel hetkel lahvatas leek ja põlema süttinud tuust pisteti juba valmis lõigatud puulaastudele lõkke südames. Laastud süttisid ja mõne aja pärast praksus keset jarangat lõke. Kohe täitus jaranga kuni sissepääsuava ülemise ääreni suitsuga.

Ronisin pologist neljakäpakil lõkke taha nahkadele ja jäin sinna külitama. Selgus, et on noore põdra püha (qaanmatgörgön). See koosneb kahest pühast. Esimene püha on "õhukesekarvalise noorte põtrade tapmise päev" (teetawnögögön). Kui ilmad lähevad külmemaks ja põtrade karv paksemaks, tuleb teine põtrade tapmisega seotud püha, mida tšuktši hõimud kutsuvad wöllgönqaanmatgörön.

Esimene püha peetakse karja tagasisaabumise puhul suvistelt karjamaadelt jarangade juurde. Nimede erinevus tulenevat sellest, et varem tapeti põtru talvevarudeks kahel korral. Esimene kord tapmine oli suvenahkade ja hilisem tapmine talvenahkade saamiseks. Nüüd piirduti paiguti ühe korraga, sest nahku vajati tunduvalt vähem - paljud tšuktšid käivad euroopalikult riides. Talvenahkade vajadusel viidi läbi ka teine tapmispüha.

Sügisene põtrade tapmine - noore põdra püha - on üks tähtsamatest tšuktši pühadest. Pidustused vältavad kolm päeva ja algavad igal hommikul tule süütamise rituaaliga. Esimesel hommikul süüdatakse lõke tulevibuga saadud tulest. Teisel hommikul tulekivi ja taelaga saadud tulest. Kolmandaks hommikuks hoitakse süsi hõõguvana spetsiaalses nõus. Tule süütamine tikust on nendel päevadel keelatud. Remkölömi sõnutsi on see kõik selleks, et tulevased põlved ei kaotaks oskust tuld üles võtta ka siis, kui tikke ei ole.

Ta ütles naljatades: "Kui tuleb tuumasõda, siis tanngid (venelased ja tšuktšidele vaenulikud rahvad) ja muud rahvad surevad ilma tuleta külma kätte, aga tšuktšid oskavad selle raske aja ikka üle elada." Tšuktšid panid pidurõivad üll. Jarangade ette süüdati tukkidega 


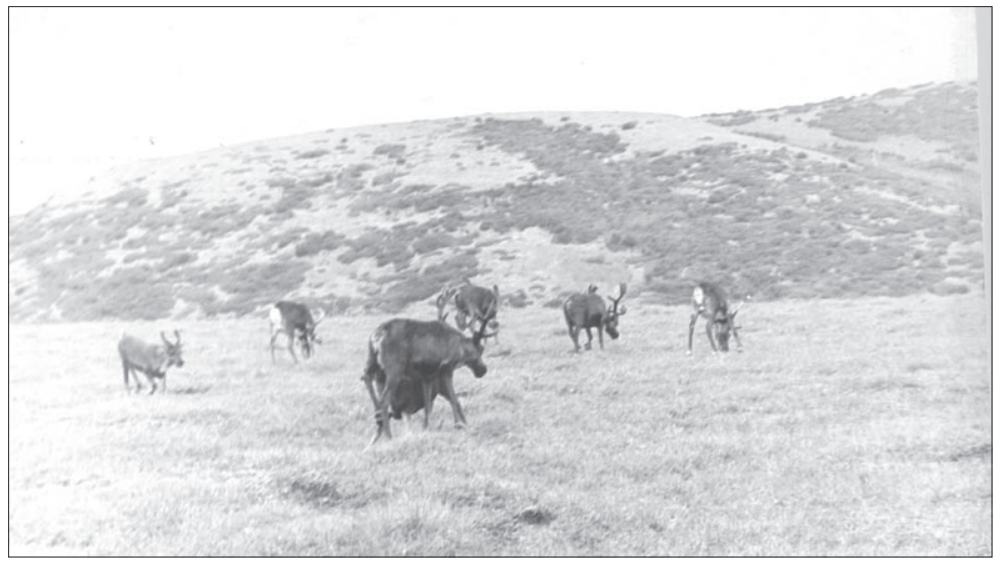

Joonis 2. Põhjapõdrad seentega maiustamas. September 1971. Foto: Erik Filips.

jarangalõkketulest uus lõke. Mehed, naised ja lapsed jäid jaranga ette ootele. Kaugusest hakkas kostma tuttavaid hõikeid: "Hackuuu, hackuuu, hack, hack, hack..." Seejärel ilmus sopka tagant nähtavale põhjapõdrakari. Lapsed lasid oma väikestest vibudest karja suunas nooli, mehed paugutasid püsse. Laskmine oli selleks, et peletada võõrastelt karjamaadelt kaasa toodud halbu vaime.

Põdrad juhiti jarangade vahelt läbi.

Hetk enne karja jõudmist jaranga juurde visati lahti uued tšaadid (nahkrihmadest lassod ehk lingud) ja nartarihmad. Kiiresti veeti nartasid ühe jaranga juurest teiseni ja tagasi ning jäeti seisma jarangade sissepääsude ette. Põdrakari tormas üle sambla peale laiali visatud uute tšaadide ja nartarihmade. Maapind müdises, kui neli ja pool tuhat looma üle maa peale visatud tšaadide ja nartarihmade jarangade vahelt läbi tormas.

Pärast püüti karja hulgast kolm valget mustade laikudega põhjapõtra: kirju isane vasikas, kirju lehm ja kirju põdrapull. See olevat olnud Ejgeli (teadjamehe) soov, kes alati määras, milliseid loomi tuli ohverdada. Seda oli ta siis õhtul vaimudelt küsinud. Loomad tiriti jarangadevahelisele alale, kus toimus traditsiooniline ohverdamine rituaalse odaga. Algul ohverdati pull, siis lehm ja lõpuks vasikas. Kõik põdrad kukkusid ohverdamisel paremale küljele. Seega 


\section{Ülo Siimets}

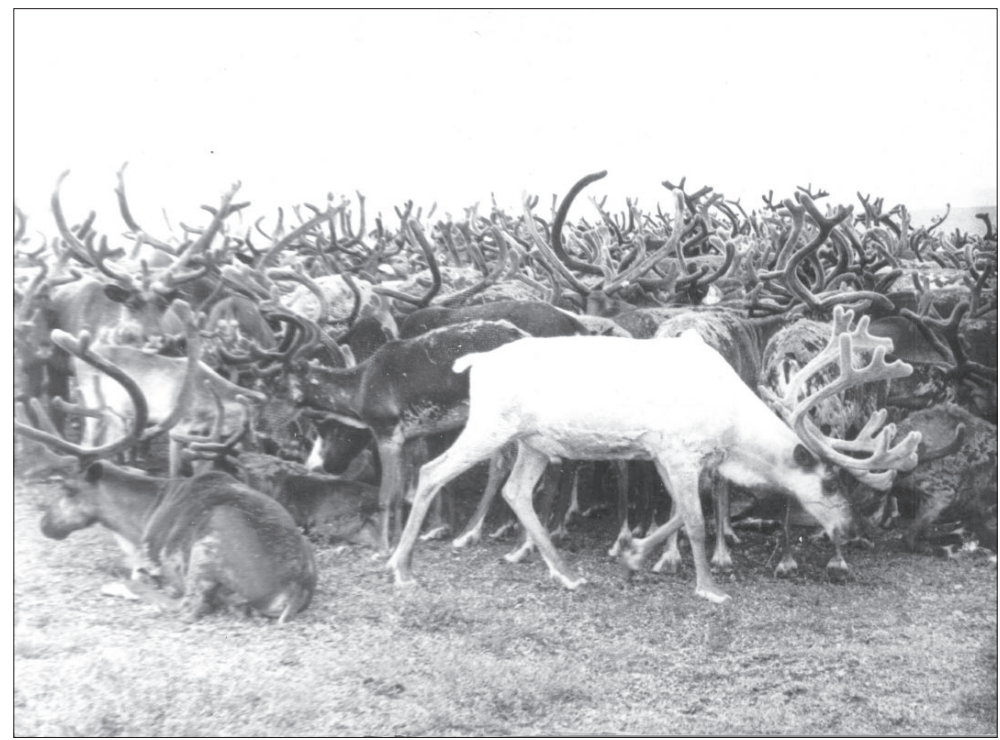

Joonis 3. Põhjapõdrakarjas oli ka valgeid põtru. Juuli või august 1971. Foto: Erik Filips.

jäi veri loomakeresse, mis näitas, et valitud põhjapõdrad meeldisid ketljale.

Mehed tõmbasid kufljankad (nahast tšuktši riietusese) üle pea ja jäid paljastatud ülakehadega seisma. Naised lasid oma kufljankakombinesoonid üle õlgade vööni alla. Torbased võeti jalast ja püksisääred tõmmati põlvini üles. Vatap käskis ka minul kalamehekummikud jalast tõmmata, presentkufljanka ja vatijope seljast visata ning ülakeha paljaks võtta, mida ma ka tegin.

Kirju põdravasikas oli ohverdatud nii, et oda ei tabanud otse südant, vaid lõikas läbi südameaordi. Selline löök tehti spetsiaalselt selleks, et loom ei sureks kohe ja ohverdamise saaks läbi viia elusa looma verega. Loom oli pikali maas ja siples. Tema rinnahaavast pulbitses iga südamelöögiga välja verd, mis haava kohal natukene hüübides vahutas.

Remkölöm kummardus, pistis näpu põdravasika verre, ajas ennast sirgu ja, jäädes seisma oma naisega vastastikku, tõmbas kõikide jaranga elanike silme all palja ülakehaga naisele veretriibud 


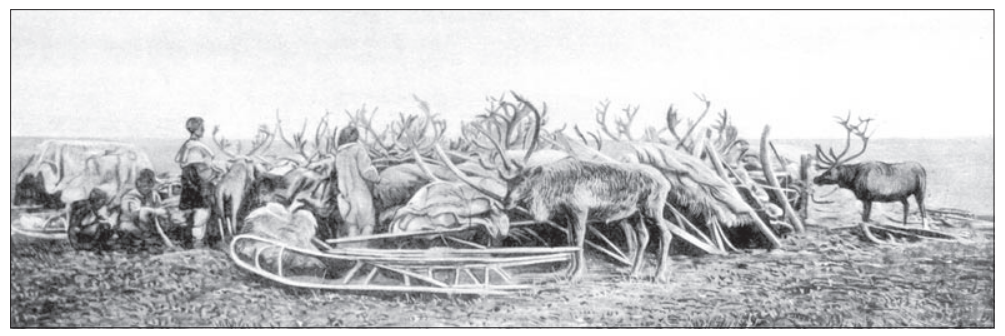

Joonis 4. Põhjapõdra ohverdamine (Bogoraz-Tan 1904).

kulmude kohale, ninale, ülevalt kõrvade juurest alla põskedele ja nina juure juurest kahele poole ning lõuale. Pärast määris naine verega mehe ja lapsed. Lisaks näole tõmmati verejutid õlaliigesele, rinnanibude alla ja naba kohale. Samuti määriti verega jalgade siseküljed pöialiigese kohalt.

Seejärel võttis Vatap verd ja tõmbas verega samasugused jutid minu näole, rinnale, kõhule ja jalgadele ning mina määrisin Vatapit verega samadest kohtadest. Pärast verega määrimist märgistati verega uued nartad. Samuti määriti verega tšaadi luuaas, kust silmuse nahknöör läbi jookseb. Verega piserdati maad jaranga ümbruses. Vatap ütles, et verd keha pealt maha pesta ei tohi, see toovat õnnetust. Sellepärast olid järgnevatel päevadel kõigil kuivanud veretriibud näol. Alles kolmandal päeval hakkas kuivanud veri vähehaaval näolt maha kooruma.

Bogoras-Tan kirjutab veremärkidega tähistamise kohta järgmist:

Igal perekonnal on omad spetsiaalsed määrimismärgid, see puudutab ka pühasid esemeid. Nad määrivad verega igal aastal sügispühade ajal kõiki pereliikmeid. Tapetakse põdravasikas, kelle verd kasutataksegi sel eesmärgil. Märgid on lihtsad: kõigest mõned jooned või rida kriipse laubal ja põskedel. Neid tehakse selleks, et nägu sarnaneks põhjapõtrade kaitsevaimu omale. Täpid silmade peal kujutavad vaimu silmi. Kaks täppi või kaks jutti põskedel on kõrvad. Kaks jutti risti põskedega on suupikendused, sest vaimul on suur suu.

Igal perel on omad märgid, mis koos pühade esemete ja majapidamisega päranduvad põlvkonnalt põlvkonnale. Kui perekond jaguneb mitmeks, saab tänu märkide sarnasusele ära hoida sugulusabielusid. Aja jooksul need märgid muidugi pidevalt muutuvad. 
Ülo Siimets

Keegi ei tohi ennast ise määrida. Harilikult määrib kõiki pereliikmeid verega pereema, alustades oma mehest. Naist ennast määrib verega tema mees. Kui peres on mitu täiskasvanud naist, määrivad nad tavaliselt üksteist.

Argentov räägib, et naine määrib mehel ja lastel verega näo, rinna ja jalgade siseküljed, seejärel joonistab mees verega naisele kriipsud samadesse kohtadesse, kuid mina ei ole kunagi kuulnud, et määritaks mingit muud kehaosa kui nägu. Kuid Jochelson teatab, et põdrakasvatajad-tšuktšid ja põdrakasvatajad-korjakid määrivad verega nägu ja kõhtu (BogorasTan 1939: 64).

Lugedes Bogoras-Tani tekkis mul mulje, et ta on palju oma märkmed kirja pannud inimeste küsitlemisel. Igatahes selles piirkonnas, kus mina viibisin, sarnanes verega määrimine pigem Argentovi ja Jochelsoni kirjeldatuga (Bogoras-Tan 1939: 64). Pealegi jätab BogorasTan peaaegu kirjeldamata verega määrimisele järgnevad sündmused. Võib-olla sellist peade teibasse ajamist ei toimunud nende tšuktši hõimude juures, mida külastas Bogoras-Tan.

Arvatavasti olid erinevatel tšuktši hõimudel erinevad verega määrimise kombed. Minu brigaadi tšuktšid ei vastanud selgitavalt küsimusele, miks me üksteist verega määrime, vaid ütlesid lihtsalt: selleks, et meil hästi läheks. Võib-olla nad enam ei teadnud selle kombe tähendust, mida kirjeldas Bogoras-Tan. Et verega määriti tähtsamaid organeid, arvasin tookord, et seda tehakse nende organite kaitseks paha vaimu eest. Hiljem sain teada, et hing on tšuktši keeles uvirit. Tšuktši rahva uskumuste järgi on inimesel peale peahinge, kes juhib kogu keha tegevust, veel palju hingesid, mis kuuluvad inimeste organite juurde. Omad hinged on jalgadel, kätel, siseorganitel. Kui inimene kaotab mõne oma organi hinge, siis see organ haigestub või koguni kängub. Viimane juhtub siis, kui hing väga pikaks ajaks kadunuks jääb. Peahinge kadumisel inimene sureb.

Šamaanid liiguvad transis olles ringi ja korjavad kadunud hingi ning teevad neist enda abilised. Hinged iseenesest on väga väikesed, umbes Vene ühe-kahekopikalise mündi suurused. Šamaanid leiavad kadunud hinged üles õrna mesilase või põrnika häält meenutava heli järgi. Tasu eest tagastavad nad need haigestunud inimesele. Hinge võivad varastada ka pahad vaimud - ketljad. Ka sel juhul jääb inimene haigeks ja võib isegi surra ning ka sellisel juhul vajatakse šamaani abi. 
Jarangadest eemale teisele poole oja tehti lõke. Tapetud põdrad viidi sinna ja asetati peaga selles suunas, kust põdrakari oli külla jooksnud.

Loomad nüliti, kusjuures pea jäeti nülgimata. Siis lõigati loomadel pea koos poole meetri pikkuse ja paarikümne sentimeetri laiuse rinnanaha riba, nn põhjapõdra habemega maha. Nimelt on põhjapõtradel rinnaesine ja lõuaalune karv ülejäänud karvadest pikem, kohati kuni $15 \mathrm{~cm}$ pikkune. Pead aeti paarimeetriste teivaste otsa ja viidi sellesse kohta, kust esimesed põhjapõdrad olid jarangade külla sisse jooksnud. Seal löödi teibad maasse ja põhjapõdrapead jäid sinna mitmeks päevaks, vahtides oma klaasistunud silmadega kaugusesse. Teiba otsas olevate peade ümber piserdati ohverdatud loomade verd. Eriti sellest suunast, kust põhjapõdrakari oli külale lähenenud. Et põhjapõdrapead olid üsna pikkade teivaste otsas, ei saanud metsloomad neid kätte. Millal pead teivaste otsast maha võeti ja kas nad üldse võeti, jäi teadmata, sest pärast pühi lahkusin koos karjustega jarangade juurest.

Lõkkele asetati suur vaskkatel ja sellesse pandi keema tapetud loomade liha. Varem olid erinevate jarangade elanikud eraldi, aga lõkke äärde kogunesid kõik külas elavad inimesed. Neid sai kokku paarkümmend. Koolilapsed olid selleks ajaks juba helikopteriga internaatkooli viidud. Seega võis selles külas olla ligi kolmkümmend elanikku.

Algul keedeti suures katlas mitmeid kordi liha. Pärast põdraliha söömist pandi lihaleeme sisse põdramaost võetud poolseeditud taimejäänused, lisati mingisuguseid söödavaid juurkaid ja mägisibulat ning kui see kõik keema läks, lisati veri. Pärast vere lisamist oodati, millal veresupp uuesti keema läks, siis lasti sellel veel umbes kolm minutit keeda. Supi valmisolekut kontrolliti luulusikaga - kui veri enam lusika külge ei kleepunud, oligi supp valmis ja katel tõsteti tulelt.

Mehed istusid katla ümber ja sõid sellest luulusikatega. Lastele ja naistele tõsteti veresuppi kaussidesse. Võib-olla oleksid naised ka katlast söönud, aga nii palju inimesi ei mahtunud selle ümber. Pärast pidulikku söömingut toodi välja bubinid ja hakati trummi põristama. Sellega alustasid täiskasvanud ja lõpetasid poisikesed. Lauldi või õigemini jorutati täishäälikutest koosnevaid viisikatkeid: "I-iii, a-aaa, o-ooo..."

Bubinit mängisid kõik pereliikmed. Lõkke peal keedeti kanget musta teed ja mehed jõid seda lõkke ääres nahkadel külitades. Tee 


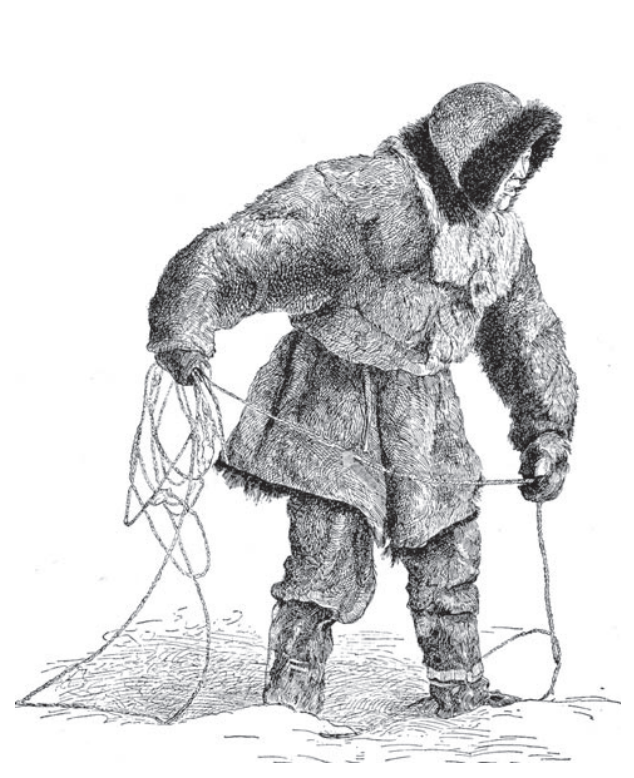

Joonis 5. Vana tšuktš lassoga (Bogoras-Tan 1904). kõrvale näriti kuivatatud punast kärbseseent (Amanita muscaria). Algul näriti kolm seenekest ja oodati natukene. Kui see ei mõjunud, s.t ei tekkinud kaifi, võeti veel kaks seent. Nii tehti seni, kuni seen hakkas mõjuma.

Mingil hetkel klaasistusid punast kärbseseent söönud inimeste silmad. Nad võtsid bubini ühte, põhjapõdravasika esijala sääreluust trummipulga teise kätte ja hakkasid trummi tagudes hüplema. Trummi hääl läks järjest metsikumaks ja hüpped muutusid üha kõrgemaks. Inimene kargles ringiratast, tuues esile metsikuid karjeid ning mingil hetkel kukkus mängija lihtsalt maha ja jäi lamama. Teised tirisid ta põdranahale ja jätsid sinna lamama.

Võtsin ka ise kolm väikest kärbseseent. Murdsin nende küljest kilde, närisin peeneks, hoidsin natukene suus ja neelasin teega alla. Seenel oli mõrkjas maitse, tavalise seene lõhn ja ta pani sülje tugevasti jooksma. Sõin seened ära ja jäin ootele. Arvatavasti olid need liiga väikesed, sest mingit mõju justkui ei järgnenud.

Siis saabus üllatus. Üks küla vanimaid naisi, kes muidu liikus keppi kasutades vaevaliselt jarangade vahel, tarvitas ka kärbseseent. Seened mõjusid talle, sest naine viskas kepi kõrvale, võttis bubini ning hakkas laulma ja hüppama. Kummaline oli näha vana inimest kõrgeid hüppeid tegemas. Mingil hetkel kukkus ka tema maha ja lohistati nahkadele lamama. Punase kärbseseene toime hirmutas mind. Kuna ma ei olnud kärbseseent kunagi kasutanud, mõtlesin, milliseid tagajärgi ta minus esile võiks kutsuda. Olin ju selle brigaadi 
kõige suurem ja kartsin, et mind ei suuda pärast keegi kinni hoida. Seepärast ma rohkem seeni ei söönud. Pimedus saabus üsna varakult. Külitasin lõkke ääres põdranahal ja jälgisin toimuvat. Aeg-ajalt kargasid mehed püsti, hakkasid bubinit taguma, karglesid mõnda aega ja kukkusid kokku. Kokkukukkunu lohistati nahale.

Enamik naisi seent ei tarvitanud. Nad istusid teisel pool lõket. Meeste hüplemiste vaheajal mõned laulsid või ümisesid, nagu ikka, täishäälikuid: "I-iii, a-aaa, ooo..."

Mind tüütas see lõpuks ära. Läksin oma pologisse ja heitsin põdranahkade vahele pikali. Trummid põrisesid veel kaua ega lasknud magama jääda. Lõpuks saabus vaikus ja ma uinusin. Vatap pologisse ei tulnudki.

Hommikul ärgates praksus keset jarangat juba lõke. Remkölöm ja Vatap külitasid nahkadel ja jõid teed. Lõkke kõrval auras katel lihaga ja lõkke kohal konksu otsas kann kuuma teega. Vatap, märgates, et pistsin pea pologist välja, kutsus mind enda kõrval lebavale nahale. Istusin rätsepistes nahale ja perenaine pani kohe ette tassi minu kuuma teega. Lauale olid asetatud suhkrutükid ja klaaskompvekid (läbipaistvad värvilised karamellkompvekid). Jõin paar lonksu ja Vatap tundis huvi, mida ma unes nägin. Vastasin, et mingit jama, aga ei suutnud meenutada.

"Kahju," vastas ta.

"Miks?" tundsin huvi.

"Pärast sellist püha on uni erilise tähendusega ja võib anda mitmeid eluks vajalike vihjeid. Õpi oma unenägusid meelde jätma," vastas Vatapi asemel mulle hoopis Remkölöm. "Unes võid näha oma saatust. Kes õpib oma unenägusid suunama nii, et ta suudab unes liikuda minevikku ja tulevikku, sellest võib saada isegi šamaan."

Olin varem Vaegis olles juba kuulnud, et tšuktšid annavad unenägudele erilise tähenduse. Mõned jahimehed pidid pärast jahti nägema unes tapetud looma. See on tunnistus sellest, et loomavaim ei ole rahul tema surma puhul läbiviidud rituaalidega. Sel juhul tuleb uuesti rituaalseid kombeid täita. Tavaliselt tehakse lõke uuesti üles ja lõkkesse pannakse looma erinevate kehaosade tükke (silmad, peaaju, jalakondiüdi, kops, maks, neerud). Eriti pidid kõikidele vaimudele meeldima maksatükid. Tihti on paremad palad, nagu näiteks silmad, juba ära söödud, ning terviklikku rituaali ei saa seetõttu läbi viia. Abiks on sellisel juhul looma kuju tegemine selle looma rasvast. Tšuktšide seas on levinud uskumus, et tapetud looma 


\section{Ülo Siimets}

rasvast sama looma kuju tegemine ja hiljem kuju ohverdamine täidab sama ülesannet kui looma ohverdamine. Kuju detailne sarnasus loomaga ei ole oluline, kuid sellega peab läbi viima samu rituaale nagu tavaliselt ohverdatud või tapetud loomade puhul.

Pereema läks mulle lõkke äärest liha tooma. Kui ta jõudis lõkke juurde, hakkas see ootamatult praksudes sädemeid pilduma.

Vatap lahendas selle praksumise probleemi väga huvitavalt, öeldes:

"Näe, tuli pillub sädemeid, külalised saabuvad."

Ma ei osanud enam midagi öelda. Meenutasin, et ka meil öeldakse mõnes maakohas, kui ahi hirmsasti praksub ja puud sädemeid pilluvad, et see viitab külaliste tulekule.

Pereema tõi mulle lõkke äärest kausiga liha ja ma hakkasin seda tükkhaaval sööma. Liha oli pooltoores nagu tavaliselt. Pealmine kiht oli kuum, aga sees oli toores, verine liha. Seega tuli teda süüa ka tavalisel moel. Võtsin nagu ikka lihatüki vasakusse kätte ja tõstsin suu juurde. Hammastega võtsin lihatükist kinni ning paremasse kätte võtsin jahinoa ja lõikasin noaga altpoolt nina suunas parajaid tükke. Hammastega andsin lihale paraja kuju ja neelasin alla. Sõin paar tükki liha ja hakkasin teed jooma.

Korraga hakkas kaugusest kostma mürinat, mis meie jarangadele lähenes. Läksime õue ja nägime, et vezdehhodiga (vene keeles amfiibauto) saabusid naaberbrigaadi tšuktšid. Kuulsin juba eile, et Remkölöm võttis raadio teel naaberbrigaadiga ühendust ja nad olid lubanud kindlasti tulla. Nüüd olid nad kohal.

Enamik tulijaid olid mulle võõrad. Olin neid Vaegis küll näinud, aga nimesid ei teadnud. Ainuke tuttav neist kuuest tulnust oli Vera Ivanovna, naaberbrigaadi zootehnik. Külalised jagati jarangade vahel. Selgus, et Vera on Remkölömi sugulane. Temale pandi polog üles Remkölömi jarangasse, lõkkest paremale.

Kui külalised olid söönud, sõideti vezdehhodiga põhjapõdrakarja juurde. Seal valis iga külaline endale meeldiva põdravasika. See loom püüti tšaadiga kinni ja tapeti noatorkega südamesse. Loom nüliti ja soovitud looma nahk anti külalisele lahkumisel kaasa. Verale kingiti kaks nahka.

Sõideti tagasi jarangade juurde. Õnneks oli ilm kuiv ja päikseline. Hea märk, et kedagi ei ole solvatud. Keedeti jälle liha ja veresuppi ning istuti lõkke ääres nahkadel. Külalised tõid välja oma kingituse. Naaberkarja brigadiril Pavel Ivanovitšil oli õnnestunud saada helikopterijuhilt või tema kaaslaselt pudel piiritust. Nüüd anti see üle 


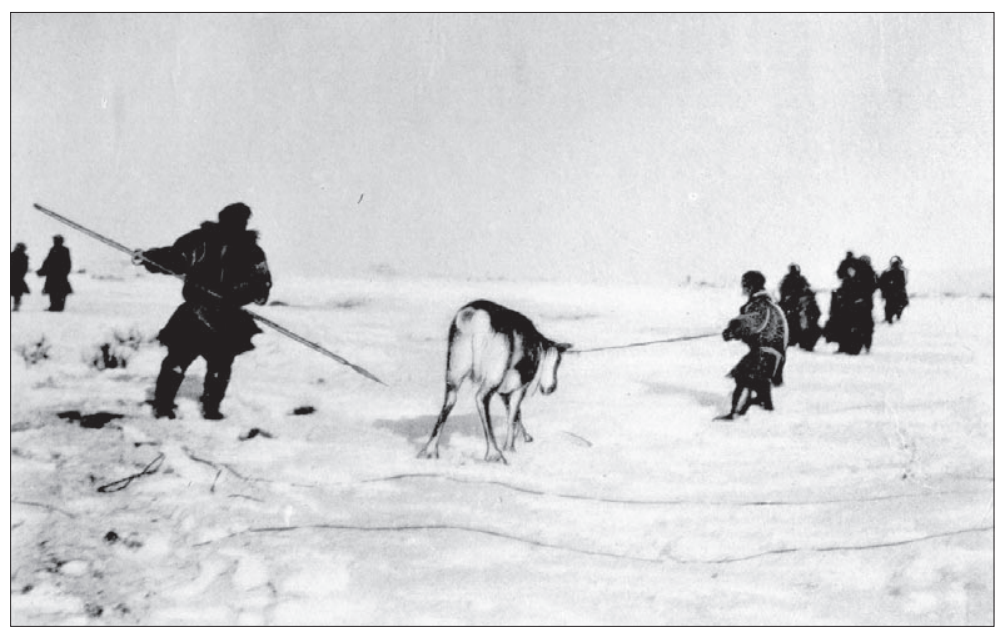

Joonis 6. Pildike Tšuktšimaalt (Bogoras-Tan 1904).

Ivan Ivanovitšile. Meie küla elanikud, eriti mehed, võtsid selle kingituse vastu suurte rõõmuhõisete saatel.

Keedeti kanget teed. Tee kallati suurde plekk-kruusi. Lisati suhkrut ja piiritust. Liitrine kruus koos sees oleva grokiga hakkas ringi käima. Meestekambaga ühines ka Vera Ivanovna, kes vahepeal oli käinud kohalike naistega uudiseid vahetamas. Kuna ta oli karjuszootehnik, siis oli ta ilmselt erand, sest oma jarangade naised hoidsid grokijoojatest eemale.

Vera Ivanovana istus minu kõrvale nahale. Ta nägu oli tätoveeritud, seega pidi ta olema sündinud enne nõukogude võimu kehtestamist Tšuktšimaal. Välimuse järgi oli Vera Ivanovna umbes kolmekümneaastane naine. Ta oli ôppinud Habarovskis zootehnikat ja veterinaariat. Naine rääkis soravalt vene keelt, igatahes paremini kui mina.

Vestlesime tšuktši kommetest. Küsisin, kas on erinevusi vanades ja praegu läbiviidavates noore põdra püha rituaalides. Vera vastas, et eelkõige sõltub see piirkonnast. Ta rääkis:

"Tšuktšimaa keskosas, nõukogude võimust kaugemates piirkondades on säilinud rohkem vanu kombeid, aga siinset piirkonda ei tabanud nõukogude võimu kehtestamisel tapatalgud. Asendusinimesed toodi tavaliselt muudest piirkondadest ja sageli ei olnud 


\section{Ülo Siimets}

nad tšuktšid. Paljudes kohtades on seetõttu vanad kombed üldse unustatud."

See maa vallutamise jutt langes üldjoontes kokku Konmgömnna räägituga (vt Mäetagused 12, lk 146).

"Varem viidi ohverdamisi tihedamalt läbi. Peale selle oli väga tähtis tuleohvrite toomine, mis praegu paljudes kohtades on üldse kadunud. Valmistati väikseid põhjapõdrarasvast kujukesi, mis ohverdati tulele. Toimusid šamaanide võistlused bubinimängus ja vaimudega suhtlemises. Kuna põhjapõdrakarjad kuulusid üksikutele rikastele, oli palju vaeseid, kelle lapsed kannatasid tihti nälga.

Noore põdra püha teisel päeval panid lapsed ja ka vaesed maskid ette ning läksid rikaste jarangadesse toitu kerjama. Nad tantsisid ja laulsid ning selle eest jagas peremees neile kingitusi. Ilma kingituseta kedagi ära saata ei tohtinud. Kingituseta külaliste minemasaatmine oleks toonud kaasa suure õnnetuse. Kõige rohkem kingitusi anti lastele, järgmisena naistele, võõrad mehed said kõige vähem kingitusi. Nina kirtsutada ei tohtinud keegi: mis sulle kingiti, sellega pidid rahul olema.

Mõnel pool oli olukord aga selline, et maskis külaline avaldas ise arvamust, millist kingitust ta ootab. Sellest ei tohtinud keelduda. Muidugi teadis peremees enamasti, kes maskis külaline on ja käitus kingitusi jagades vastavalt."

Rääkisin Verale eesti mardi- ja kadrisantidest ja leidsime, et midagi ühist on võimalik leida arvatavasti kõikide rahvaste kommetes. Vera jätkas:

"Pühade ja ohverduste ajal tšuktšid ennustasid. Selleks kasutati erinevate loomade, enamasti põdravasika pealuud. Metslooma pealuuga oli lihtsam saada jahialaseid vastuseid, põdrapealuuga karja puudutavaid vastuseid. Pealuu riputati põdrajalakõõlustest nööriga paarimeetrise ridva või kaika külge. Ennustuseset hoiti kas jarangas maapinnal või avatundras samblal. Kõval häälel esitati küsimus ja kepi külge riputatud ese tõsteti ülesse. Kui ta hakkas kõikuma, oli vastus jaatav, kui jäi seisma või tegi väikesi ringe, siis eitav. Isegi kui kerge sõrmetõukega anda pealuule kindel liikumissuund, pidada ta eitava vastuse korral kiiresti seisma jääma. Selline "abistamine" on mõistagi keelatud ja tavaliselt keegi nii ei teegi.

Küsimusi saab esitada ka inimeste tervise ja tuleviku kohta. Sel juhul pandi inimene põdranahale selili ja muu oli sama. Tema rinna või kõhu kohalt üles tõstetud pealuu vastas küsimustele. Selliseid 
ennustusi viisid läbi šamaanid või nende abilised. Nüüd tuleb selliseid olukordi harva ette, sest võimud kiusavad šamaane taga ja kuulsamad neist tapeti juba nõukogude võimu tulekul."

Meie kõneluse katkestas Ejgeli, kes järjekordselt jutustas, kuidas valge mees püüdis kiviga karu tappa, visates karule kiviga vastu selga, ning kuidas karu Jelole (s.t mulle - autori märkus) kallale tormas, jäädes peatuma seitsme meetri kaugusele. Jutustades hüppas ta püsti ja näitas, kuidas karu seisis, kaks käppa püsti. Kuidas Jelo seisis, nuga käes, ja kuidas Ejgeli karule karusõnade lasumisega selgeks tegi, et tšuktšid ja karud on hõimlased, ning kuidas karu selle peale maha istus ja lõpuks lahkus (vt Mäetagused 11: 147150). Selle peale ütles Remkölöm:

"Jelo on tubli. Küllap sai karu ka aru, et ta on üks tšuktši verd

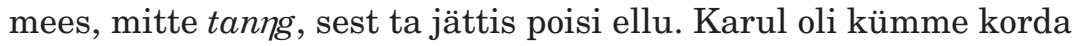
enne Ejgeli kohale jõudmist võimalik poisile käpaga pähe anda ja skalp kaasa võtta. Karu ei teinud seda, vaid uudistas meest kahe käpa peal. Hiljem selgus, et karul on õigus. Jelo suutis üksi, ilma koerata terve põhjapõdrakarja kokku ajada, kui Nuwat kärbseseeneuimas samblale magama jäi. Nuwati koer kuulab ainult peremeest ja jäi Nuwatit valvama, kui too magas. Jelost saaks tõeline tšuktš. Meie nooredki ei pea põdrakarjas vastu, vaid otsivad linnadest ja küladest kergemat elu. Jää meie juurde, anname sulle uue nime. Praegune nimi on imelik - Lõhutud Sõber. (Tšuktši keeles jelo tähendab sõpra, Siimets kõlab nagu simete, mis tähendab lõhutud - autori märkus.) Ma saan aru, kui inimese nimi on Sõber, aga miks pead sa olema Lõhutud Sõber. Annaksime sulle uue, parema nime."

"Huvitav oleks teada, millise nime tee mulle annaksite?"

"Noh, näiteks Karukütt või midagi taolist. Karusid sa kogu aeg püüad taga ajada, kuigi ega see ka päris õige ole."

"Ise te tapate ka karusid igal võimalikul juhul."

"Kui sa oled tähele pannud, siis teeme seda ainult juhul, kui nad karjale liiga teevad või liiga ülbeks muutuvad. Vahel lastakse muidugi mõni toidu vahelduseks, aga mitte kunagi ainult lõbu pärast. Lõbu pärast tapavad ainult tanๆgid ja muud valged. Mäletad,

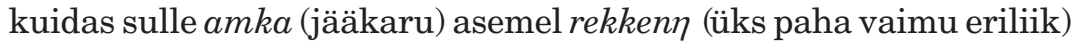
kaela saadeti. Peaaegu oleks ta teid omaks võtnud. Ejgeli pidi kaua loitsima, et ta meile kallale ei tuleks. Muidugi võis ta ka kosatko olla. See oli hoiatuseks, et sa karusid ei kiusaks." 


\section{Ülo Siimets}

"See oli siiski amka," püüdsin ennast õigustada (amka on tšuktši keeles jääkaru). "Kui oleksin järgmisel päeval saanud talle järele minna, kaunistaks tema nahk minu elamist."

"Isegi kui ta oli amka, siis ketlja ei tahtnud, et sa ta tabaksid, muidu oleks ta surnud. Tema jooksis ju minema."

Selle peale tundsid teise brigaadi karjused huvi, mis juhtus, ja Ivan Ivanovitš oli sunnitud jutustama, kuidas Jelo ja Ejgeli rekken it jahtisid ning kuidas Ejgeli oli sunnitud pool ööd loitsima, et pahadest vaimudest lahti saada. Ma püüdsin küll ennast õigustada:

"Meil Eestis jälitatakse haavatud loomi seni, kuni nad kätte saadakse, või vähemalt 24 tundi. Kui on tegemist tugevalt haavatud karuga, siis tuleks seda veel eriti teha. Haavatud karu ei saa magama jääda ja uitab ringi. Sööki on karul talvel raske kätte saada ning ta hakkab ründama inimesi ja loomi. Sellest tulevadki šaitanid. Eelmisel talvel räägiti Vaegis pidevalt, et šaitan hulgub ringi.”

Minu jutt ei suutnud tšuktšide arvamust kõigutada: nad jäid kindlaks, et kui loom jahi lõpus põgenema pääseb, tahab ketlja, et ta jääks ellu.

Aeg mõõdus kiiresti. Pimedus oli jälle käes. Grokijoojate keeled läksid juba pehmeks ja nende jutust ei olnud enam midagi mõistlikku aru saada. Nende väikestele keredele mõjus alkohol kiiremini ja piisas väikesest kogusest. Aeg-ajalt põristas keegi bubini ja laulis oma täishäälikutest koosnevat meloodiat: "Iiii-aaa-uuu..."

Läksin jarangasse ja püüdsin magama jääda. Uni ei tulnud. Kuulsin, et keegi sisenes jarangasse. Siis oli kuulda naha sahinat ja keegi tõstis minu pologi riide üles. Arvasin, et Vatap tuli ka pologisse magama. Kuid tulija ei läinud oma poole peale, vaid keeras ennast minu suunas. Ta juuksed riivasid minu nägu ja ta surus huuled minu omadele. Sirutasin käed nahkade alt välja ja Vera alasti keha vajus minu käte vahele.

Ta sosistas: "Ma tulin sinu juurde. Sa meeldid mulle."

Tore oli üle pika aja jälle naisega olla.

Hommikul einestasime jarangas. Pärast jätsime naaberbrigaadi karjustega hüvasti. Nad istusid oma vezdehhodi ja lahkusid.

Meid ootas ees noore põdra püha kolmas päev. See päev oli lihavarumise päevaks. Tapeti kehvemaid, haigeid ja vigaseid emasloomi. Tapeti ka nõrgemate sarvedega pulle ja nigelamaid vasikaid. 


\section{Ülo Siimets}

Loomad tuli nülgida ja tükeldada. Lihale lõigati noaga iga paari sentimeetri tagant sälgud. Sälgutatud liha riputati soolamata lihakuivatamisõrtele. Loomade need osad, mida tavaliselt söödi toorelt (kõõlused, suunahad jne) pandi hülgenahast kottidesse ja kallati verega üle. Kotid koos sisuga asetati igikeltsa raiutud aukudesse, kuhu need jäid ootama toidulauale kandmist. Tööd jätkus kõikidele külaelanikele terveks päevaks ja ma arvan, et õhtul vajusid kõik väsinult nahkadele. Igatahes mina magasin järgmisel ööl sügavat ja rahulikku und.

\section{Kasutatud kirjandus}

Bogoras-Tan, V. 1939. Чукчи. Leningrad. 